Jurnal SOROT Vol 8 No 1 April hal 1 - 104

Lembaga Penelitian Universitas Riau

\title{
PENGARUH KEAHLIAN, INDEPENDENSI, KECERMATAN PROFESIONAL, DENGAN ETIKA SEBAGAI VARIABEL MODERASI TERHADAP KUALITAS AUDITOR PADA INSPEKTORAT PROVINSI BENGKULU
}

\author{
Erwin Febriansyah ${ }^{*}$, M. Rasuli ${ }^{2}$, Hardi $^{2}$ \\ 'Program Studi Magister Akuntansi Pasca Sarjana,Universitas Riau \\ 2 Dosen Fakultas Ekonomi, Universitas Riau \\ E-mail : erwinfebriansyah@gmail.com
}

\begin{abstract}
This research was conducted using a survey method in Inspectorate Bengkulu Province. This study aims to examine the influence of expertise, independence, due proffesional care, with ethics as a moderating variable to quality auditor in the Inspectorate Bengkulu province. The population in this study was 60 auditors in Inspectorate Bengkulu Province. The data was collected by distributing kuesinoner to the 60 respondents, but only 55 questionnaires that can be used in this study. Type of data used is primary data with the method of data collection using questionnaires. Method of data analysis used in this study is multiple regression (multiple regression). These results indicate that the effect on the quality auditor expertise. Ethics can moderate the influence of expertise on audit quality. Independence has an influence on the quality of auditors. Ethics can moderate the impact on the quality of auditor independence. Due proffesional care has an influence on the quality of auditors. Ethics can moderate the influence of due proffesional care to quality auditor. The coefficient of determination $\left(\mathrm{R}^{2}\right)$ of 0.672 illustrates that $67.2 \%$ influenced by the quality auditor expertise, independence, due proffesional care, and ethics, while 32.8 $\%$ is influenced by other variables.

Keywords: Expertise, Independence, Due professional care, Ethics, Quality Auditor
\end{abstract}

\section{PENDAHULUAN}

Saat ini masih ada daerah yang belum siap dengan sistem pemerintahan yang baru untuk menyelenggarakan pemerintahan daerah sesuai dengan tata kelola pemerintahan yang baik. Telah terjadi kasus di sejumlah daerah yang berkaitan dengan masalah korupsi, ketidakberesan, penyalahgunaan wewenang dan jabatan, pelanggaran, dan masih banyak lagi kasus pidana lainnya.

Lemahnya pengendalian internal dalam penyelenggaraan pemerintahan daerah merupakan salah satu penyebab terjadinya ketidakefisienan dan ketidakefektifan penyelenggaraan pemerintahan daerah dan tentunya berdampak pada pemborosan anggaran dan keuangan daerah. Disamping itu, akibat lemahnya pengendalian internal dalam penyelenggaraan pemerintahan daerah, ada sebagian oknum di lingkungan pemerintahan daerah yang tidak atau belum siap dengan berlakunya otonomi daerah, terutama berkaitan dengan masalah etika dan moral dari oknum pejabat pemerintahan daerah tersebut yang rendah. 
Di sisi lain, masih menjadi tanda tanya besar di kalangan profesi audit internal mengenai peran serta dari fungsi pengawasan termasuk para pejabat pengawas yang berada di lingkungan fungsi pengawasan atau inspektorat daerah, baik tingkat provinsi, kabupaten, maupun kota, terutama dalam upaya untuk mengawal berbagai kegiatan dan program pemerintah daerah dalam penyelenggaraan pemerintahan daerah yang memenuhi prinsip tata kelola pemerintahan daerah yang baik dan dapat dipertanggungjawabkan (Ashari, 2011).

Inspektorat merupakan suatu lembaga pengawasan di lingkungan pemerintahan daerah, baik untuk tingkat provinsi, kabupaten, atau kota, memainkan peran yang sangat penting dan signifikan untuk kemajuan dan keberhasilan pemerintah daerah dan perangkat daerah di lingkungan pemerintahan daerah dalam menyelenggarakan pemerintahan di daerah dan mencapai tujuan dan sasaran yang telah ditetapkan. Dengan semakin meningkatnya tuntutan masyarakat atas penyelenggaraan pemerintahan yang bersih, adil, transparan, dan akuntabel harus disikapi dengan serius dan sistematis. Segenap jajaran penyelenggara negara, baik dalam tataran eksekutif, legislatif, dan yudikatif harus memiliki komitmen bersama untuk menegakkan good governance dan clean government.

Beberapa hal yang terkait dengan kebijakan untuk mewujudkan good governance pada sektor publik antara lain meliputi penetapan standar etika dan perilaku aparatur pemerintah, penetapan struktur organisasi dan proses pengorganisasian yang secara jelas mengatur tentang peran dan tanggung jawab serta akuntabilitas organisasi kepada publik, pengaturan sistem pengendalian organisasi yang memadai, dan pelaporan eksternal yang disusun berdasarkan sistem akuntansi yang sesuai dengan standar akuntansi pemerintahan.

Berdasarkan Peraturan Menteri Negara Pendayagunaan Aparatur Negara No. Per/o5/M.Pan/03/2008 tanggal 31 Maret 2008, menyatakan ada empat faktor yang dapat mempengaruhi kualitas auditor, yaitu keahlian, independensi, kecermatan profesional, sedangkan kepatuhan pada kode etik didasarkan atas Permendagri No. 28 Tahun 2007 tanggal 30 Mei 2007 tentang Norma Pengawasan dan Kode Etik Pejabat Pengawas Pemerintah.

Tujuan Penelitian ini adalah untuk (1) membuktikan secara empiris bahwa keahlian berpengaruh terhadap kualitas auditor pada Inspektorat Provinsi Bengkulu; (2 membuktikan secara empiris bahwa etika akan mempengaruhi keahlian terhadap kualitas auditor pada Inspektorat Provinsi Bengkulu; (3) Untuk membuktikan secara empiris bahwa independensi berpengaruh terhadap kualitas auditor pada Inspektorat Provinsi Bengkulu; (4) membuktikan secara empiris bahwa etika akan mempengaruhi independensi terhadap kualitas auditor pada Inspektorat Provinsi Bengkulu; (5) membuktikan secara empiris bahwa kecermatan profesional berpengaruh terhadap kualitas auditor pada Inspektorat 
Provinsi Bengkulu; dan (5) membuktikan secara empiris bahwa etika akan mempengaruhi kecermatan profesional terhadap kualitas auditor pada Inspektorat Provinsi Bengkulu.

\section{TINJAUAN PUSTAKA}

\section{Keahlian Audior}

Kualitas auditor menurut Peraturan Menteri Negara Pendayagunaan Aparatur Negara No. Per/o5/M.Pan/o3/2008 tanggal 31 Maret 2008 adalah auditor yang melaksanakan tupoksi dengan efektif, dengan cara mempersiapkan kertas kerja pemeriksaan, melaksanakan perencanaan, koordinasi dan penilaian efektifitas tindak lanjut audit, serta konsistensi laporan audit. Berdasarkan Peraturan Menteri Negara Pendayagunaan Aparatur Negara No. Per/o5/M.Pan/o3/2008 tanggal 31 Maret 2008 menyatakan auditor harus mempunyai pengetahuan, keterampilan dan kompetensi lainnya yang diperlukan untuk melaksanakan tanggung jawabnya.

Independensi dapat dikategorikan kedalam dua aspek, yaitu: independensi dalam kenyataan (independence in fact) dan independensi dalam penampilan (independence in appearance). Independensi dalam kenyataan ada apabila akuntan publik berhasil mempertahankan sikap yang tidak bias selama audit, sedangkan independensi dalam penampilan adalah hasil persepsi pihak lain terhadap independensi akuntan publik (Arens dan Loebbecke, 2008: 47).

Auditor harus menggunakan keahlian profesionalnya dengan cermat dan seksama (due professional care) dan secara hati-hati (prudent) dalam setiap penugasan. Due professional care dapat diterapkan dalam pertimbangan profesional (professional judgment), meskipun dapat saja terjadi penarikan kesimpulan yang tidak tepat ketika audit sudah dilakukan dengan seksama. Auditor harus mematuhi kode etik yang ditetapkan. Pelaksanaan audit harus mengacu pada standar audit ini, dan auditor wajib mematuhi kode etik yang merupakan bagian yang tidak terpisahkan dari standar audit.

\section{Penelitian Terdahulu}

Alim (2007), Elfarini (2007), Huntoyungo (2009), Lubis (2009), Efendy (2010), Ardini (2010), Ashari (2011), menyatakan bahwa kompetensi berpengaruh terhadap kualitas auditor. Alim (2007), Elfarini (2007), Lubis (2009), Wati (2010), Singgih (2010), Lubis (2010), Ardini (2010), Subhan (2011), Ashari (2011), Marsellia (2012), Saripudin (2012), menyatakan bahwa independensi berpengaruh terhadap kualitas auditor. Lubis (2009), Singgih (2010), Subhan (2011), Hardiningsih (2012), menyatakan bahwa kecermatan profesional berpengaruh terhadap kualitas auditor. Lubis (2009), Subhan (2011), Ashari (2011), Hardiningsih (2012). Sedangkan Kisnawati (2012) menyatakan bahwa kompetensi tidak berpengaruh terhadap kualitas auditor. Alim (2007), Kitta (2009), menyatakan bahwa interaksi keahlian terhadap kualitas auditor 
yang dipengaruhi etika tidak berpengaruh. Kisnawati (2012) menyatakan bahwa independensi tidak berpengaruh terhadap kualitas auditor. Samsi (2013) menyatakan bahwa interaksi independensi terhadap kualitas auditor yang dipengaruhi oleh etika tidak berpengaruh terhadap kualitas auditor. Huntoyungo (2009), dan Saripudin (2012) menyatakan bahwa kecermatan profesional tidak berpengaruh terhadap kualitas auditor. Ashari (2011) menyatakan bahwa etika tidak berpengaruh terhadap kualitas auditor.

\section{Kerangka Pemikiran}

Auditor yang berpendidikan tinggi akan mempunyai pandangan yang lebih luas mengenai berbagai hal. Auditor akan semakin mempunyai banyak pengetahuan mengenai bidang yang digelutinya, sehingga dapat mengetahui berbagai masalah secara lebih mendalam. Selain itu dengan ilmu pengetahuan yang cukup luas, auditor akan lebih mudah dalam mengikuti perkembangan yang semakin kompleks. (Meinhard et. al, 1987 dalam Harhinto 2004). Huntoyungo (2009) melakukan penelitian pada Inspektorat Provinsi Gorontalo mengenai faktor-faktor yang berpengaruh pada kualitas audit dimana hasil penelitiannya menggambarkan bahwa keahlian dan independensi berpengaruh signifikan terhadap kualitas audit.

Peraturan Menteri Dalam Negeri No. 28 Tahun 2007 tanggal 30 Mei 2007 tentang Norma Pengawasan dan Kode Etik Pejabat Pengawas Pemerintah dalam ketentuan umum pasal 1 point 2 menyebutkan kode etik pejabat pengawas pemerintah adalah seperangkat prinsip moral atau nilai yang dipergunakan oleh pejabat pengawas pemerintah sebagai pedoman tingkah laku dalam melaksanakan tugas pengawasan. Penelitian yang dilakukan oleh Behn et al. (1997) dalam widagdo et al. (2002) dengan hasil penelitian yang menyatakan bahwa interaksi keahlian dan etika berpengaruh signifikan terhadap kualitas auditor.

Independensi dapat dikategorikan kedalam dua aspek, yaitu: independensi dalam kenyataan (independence in fact) dan independensi dalam penampilan (independence in appearance). Independensi dalam kenyataan ada apabila akuntan publik berhasil mempertahankan sikap yang tidak bias selama audit, sedangkan independensi dalam penampilan adalah hasil persepsi pihak lain terhadap independensi akuntan publik (Arens dan Loebbecke, 2003). Penelitian yang dilakukan oleh Alim (2007), Elfarini (2007), Lubis (2009), Wati (2010), Singgih (2010), Lubis (2010), Ardini (2010), Subhan (2011), Ashari (2011), Marsellia (2012), Saripudin (2012), menyatakan bahwa independensi berpengaruh terhadap kualitas auditor.

Dengan kepatuhan pada kode etik yang dimiliki, auditor akan mampu mempertahankan sikap mental independen. Independen disini berarti auditor tersebut memiliki sikap yang netral dan tidak bias serta menghindari konflik kepentingan dalam merencanakan, melaksanakan dan melaporkan pekerjaan 
yang dilakukannya (Alim, 2007). Alim (2007) dalam penelitiannya mengenai Pengaruh kompetensi dan independensi terhadap kualitas auditor sebagai etika editor sebagai variabel moderasi. Hasil penelitiannya adalah interaksi independensi dan etika auditor berpengaruh signifikan terhadap kualitas audit.

Pada standar umum ketiga (SPKN, 2007) yang mengatur mengenai penggunaan kemahiran profesional secara cermat dan seksama menyebutkan bahwa "Dalam pelaksanaan pemeriksaan serta penyusunan laporan hasil pemeriksaan, pemeriksa wajib menggunakan kemahiran profesionalnya secara cermat dan seksama". Lubis (2009) pada hasil penelitiannya menyatakan bahwa kecermatan profesional berpengaruh terhadap kualitas auditor. Auditor harus mematuhi kode etik yang ditetapkan. Pelaksanaan audit harus mengacu pada standar audit ini, dan auditor wajib mematuhi kode etik yang merupakan bagian yang tidak terpisahkan dari standar audit (Lubis, 2009).

\section{Hipotesis}

1. Keahlian berpengaruh terhadap Kualitas Auditor

2. Etika akan mempengaruhi hubungan antara Keahlian dengan kualitas auditor

3. Independensi berpengaruh terhadap Kualitas Auditor

4. Etika akan mempengaruhi hubungan antara Independensi dengan Kualitas Auditor

5. Kecermatan Profesional berpengaruh terhadap Kualitas Auditor

6. Etika akan mempengaruhi hubungan Kecermatan Profesional dengan Kualitas Auditor

\section{METODOLOGI}

Populasi dalam penelitian ini adalah 60 auditor pada Inspektorat Provinsi Bengkulu. Pengambilan sampel dilakukan dengan menggunakan metode purposive sampling. Sedangkan responden dalam penelitian ini yaitu auditor pada Inspektorat Provinsi Bengkulu. Data penelitian yang digunakan adalah data primer, yaitu data yang dikumpulkan dengan menyebarkan daftar pertanyaan (kuesioner) yang akan diisi atau dijawab oleh para auditor pada Inspektorat Provinsi Bengkulu.

\section{Definisi Operasionalisasi Variabel dan Pengukurannya}

Keahlian (Variabel Independen); Auditor harus mempunyai pengetahuan, keterampilan, dan kompetensi lainnya yang diperlukan untuk melaksanakan tanggung jawabnya. Bedard (1986) mengartikan keahlian atau kompetensi sebagai seseorang yang memiliki pengetahuan dan keterampilan prosedural yang luas yang ditunjukkan dalam pengalaman audit. Berdasarkan uraian di atas dapat ditarik kesimpulan bahwa kompetensi auditor adalah auditor yang dengan 
pengetahuan dan pengalaman yang cukup dan eksplisit dapat melakukan audit secara objektif, cermat dan seksama.

Independensi (Variabel Independen); Auditor harus memiliki sikap netral dan tidak bias serta menghindari kepentingan dalam merencanakan, melaksanakan dan melaporkan pekerjaan yang dilakukannya. (Arens dan Loebbecke, 2008).

Kecermatan Profesional (Variabel Independen); Auditor harus menggunakan keahlian profesionalnya dengan cermat dan seksama (due professional care) dan secara hati-hati (prudent) dalam setiap penugasan. Auditor harus menggunakan kemahiran profesional secara cermat dan seksama dalam menentukan jenis pemeriksaan yang akan dilaksanakan dan standar yang akan diterapkan terhadap pemeriksaan.

Etika (Variabel Moderating); Auditor harus mematuhi kode etik yang telah ditetapkan. Pelaksanaan audit harus mengacu kepada Standar Audit dan wajib mematuhi kode etik yang merupakan bagian yang tidak terpisahkan dari standar audit. Auditor dalam melaksanakan tugas mentaati peraturan perundangundangan dengan penuh pengabdian, kesadaran dan tanggungjawab dengan cara wajib bersikap dan berperilaku sesuai dengan kode etik.

Kualitas Auditor (Variabel Dependen); Kualitas auditor menurut Peraturan Menteri Negara Pendayagunaan Aparatur Negara No. Per/05/M.Pan/03/2008 tanggal 31 Maret 2008 adalah auditor yang melaksanakan tupoksi dengan efektif, dengan cara mempersiapkan kertas kerja pemeriksaan, melaksanakan perencanaan, koordinasi dan penilaian efektifitas tindak lanjut audit, serta konsistensi laporan audit.

Pengukuran variabel-variabel menggunakan instrumen berbentuk pertanyaan tertutup. Instrumen berjumlah 24 butir pertanyaan yang berhubungan dengan variabel independen yang diteliti serta diukur menggunakan skala Likert dari 1 s.d. 5. responden diminta memberikan pendapat setiap butir pertanyaan, mulai dari sangat tidak setuju sampai sangat setuju. Alasan penggunaan skala Likert 1 s.d. 5 adalah untuk memudahkan responden dalam memilih jawaban.

Tabel 1: Nilai Jawaban

\begin{tabular}{|l|c|}
\hline \multicolumn{1}{|c|}{ Jawaban } & Nilai \\
\hline Sangat tidak setuju (STS) & 1 \\
Tidak setuju (TS) & 2 \\
Netral (N) & 3 \\
Setuju (S) & 4 \\
Sangat setuju (SS) & 5 \\
\hline
\end{tabular}

\section{Analisis Data}


Menurut Ghozali (2005) Untuk menguji regresi dengan variabel moderating digunakan uji interaksi yang merupakan aplikasi khusus regresi berganda linear dimana persamaan regresi nya mengandung unsur interaksi (perkalian dua atau lebih variabel independen). Model persamaan MRA yang digunakan:

$$
Y=a+b_{1} X_{1}+b_{2} X_{2}+b_{3} X_{3}+b_{4} X_{4}+b_{5} X_{1} X_{4}+b_{6} X_{2} X_{4}+b_{7} X_{3} X_{4}+e
$$

Di mana:

$$
\begin{array}{ll}
\mathrm{Y} & =\text { Kualitas auditor } \\
\mathrm{b}_{1}, \mathrm{~b}_{2}, \mathrm{~b}_{3}, \ldots, \mathrm{b}_{7} & =\text { Koefisien regresi } \\
\mathrm{X}_{1} & =\text { Keahlian } \\
\mathrm{X}_{2} & =\text { Independensi } \\
\mathrm{X}_{3} & =\text { Kecermatan Profesional } \\
\mathrm{X}_{4} & =\text { Etika } \\
\mathrm{a} & =\text { Konstanta } \\
e & =\text { Galat (error terms) }
\end{array}
$$

\section{HASIL PENELITIAN DAN PEMBAHASAN}

\section{Hasil Penelitian}

Penelitian ini menggunakan kuesioner untuk pengumpulan data yang dikirimkan kepada Inspektorat Provinsi Bengkulu. Pengiriman daftar pertanyaan diantar langsung untuk menjaga kepastian sampainya daftar pertanyaan ke tangan responden. Dari 60 kuesioner yang dikirimkan, kuesioner yang kembali sebanyak 60 (100\%). Kuesioner yang dapat diolah sebanyak 55 (91,67\%).

Analisis data dilakukan terhadap 55 jawaban responden yang memenuhi kriteria untuk dilakukan pengolahan data.

Tabel 2: Deskripsi Variabel

\begin{tabular}{|l|c|c|c|}
\hline \multicolumn{1}{|c|}{ Uraian } & Rerata & Simpangan Baku & N \\
\hline Keahlian & 24.55 & 1.874 & 55 \\
\hline Independensi & 24.45 & 1.653 & 55 \\
\hline Kecermatan Profesional & 12.24 & .860 & 55 \\
\hline Etika & 16.27 & .827 & 55 \\
\hline Kualitas Auditor & 20.44 & 1.932 & 55 \\
\hline
\end{tabular}

Sumber: Pengolahan Data Hasil Penelitian, 2013

Dari Tabel 2 dapat dilihat, bahwa rata-rata jawaban responden untuk variabel Keahlian adalah 24.55, diperoleh standar deviasi 1.874. Independensi dengan nilai rata-rata jawaban responden 24.45 diperoleh standar deviasi 1.653 . 
Kecermatan Profesional dengan nilai rata-rata 12.24 diperoleh standar deviasi 0.860. Etika dengan nilai rata-rata 16.27 diperoleh standar deviasi 0.827 . Kualitas Auditor dengan nilai rata-rata 20,44 diperoleh standar deviasi 1.932. Dilihat dari rata-ratanya, variabel Keahlian memiliki rata-rata paling tinggi dibandingkan dengan variabel lainnya.

Berdasarkan uji validitas butir-butir pertanyaan dalam kuesioner penelitian ini dengan menggunakan Korelasi Pearson melalui aplikasi SPSS, setiap butir pertanyaan berkorelasi positif terhadap skor total dengan signifikansi pada level 0.05. Untuk mengetahui validitas setiap butir pertanyaan pada kuesioner, maka $\mathbf{r}_{\text {hitung }}$ dibandingkan dengan range yang dipakai untuk mengukur validitas yaitu berada disekitar angka $-1,0$ dan +1 . Jika rhitung semakin mendekati angka 1, maka item pertanyaan tersebut valid, dan sebaliknya jika $\mathrm{r}_{\text {hitung }}$ mendekati angka o (makin menjauhi angka 1) maka item pertanyaan tersebut tidak valid digunakan dalam sebuah penelitian.

Pengujian reliabilitas penelitian ini menggunakan koefisien Cronbach Alpha dengan taksiran batasan minimal o.5. Variabel penelitian akan dikatakan reliabel jika Cronbach Alpha-nya memiliki nilai lebih besar dari o.6. Sebaliknya jika koefisien alpha instrumen lebih rendah dari 0.6 maka instrumen tersebut tidak reliabel untuk digunakan dalam penelitian.

Tabel 3: Uji Reliabilitas

\begin{tabular}{|l|c|c|}
\hline \multicolumn{1}{|c|}{ Variabel } & $\begin{array}{c}\text { Koefisien } \\
\text { Cronbach Alpha }\end{array}$ & $\begin{array}{c}\text { Jumlah Item } \\
\text { Pertanyaan }\end{array}$ \\
\hline Keahlian & 0.712 & 6 \\
\hline Independensi & 0.752 & 6 \\
\hline Kecermatan Profesional & 0.900 & 3 \\
\hline Etika & 0.856 & 4 \\
\hline Kualitas Auditor & 0.876 & 5 \\
\hline
\end{tabular}

Sumber: Pengolahan Data Hasil Penelitian, 2013

Untuk melihat normalitas rata-rata jawaban responden yang menjadi data dalam penelitian ini dapat dilihat dari normal probability plot. Jika data menyebar disekitar garis diagonal dan mengikuti arah garis diagonal, maka model regresi memenuhi asumsi normalitas. Sebaliknya jika data menyebar secara acak dan tidak berada di sekitar garis diagonal, maka asumsi normalitas data tidak terpenuhi. Normal probability plot pada penelitian ini terlihat pada Gambar 1. berikut: 


\section{Dependent Variable: Kualitas Auditor}

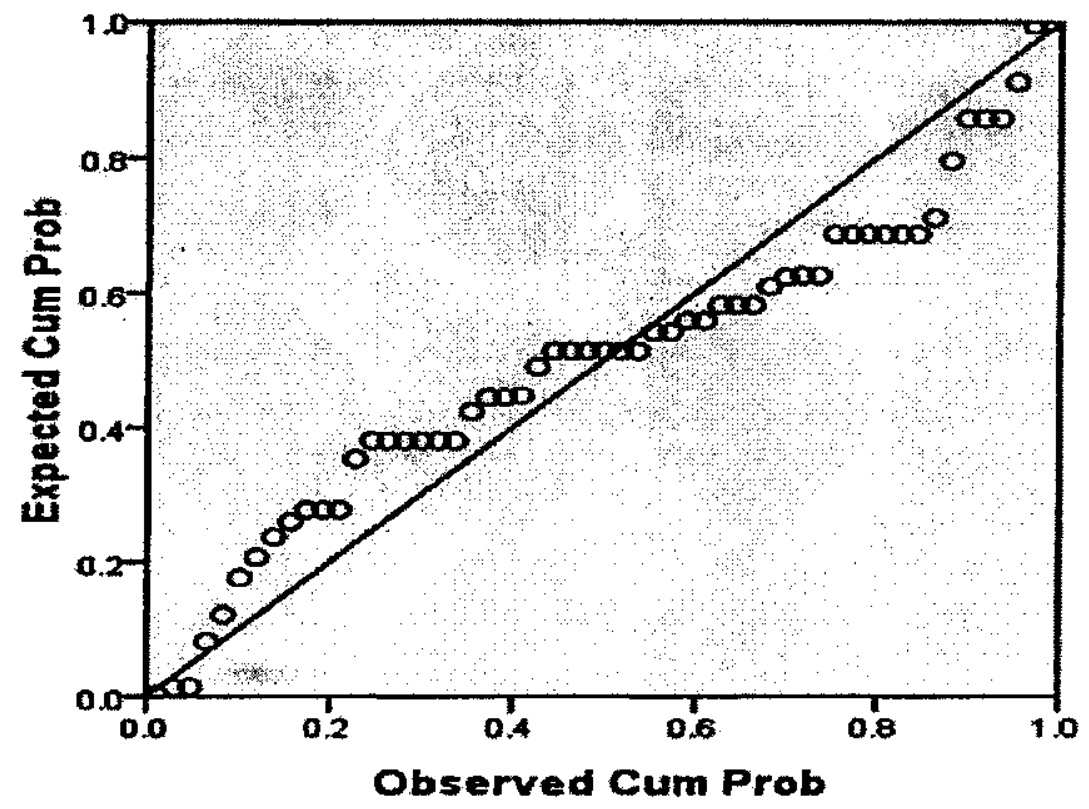

\section{Gambar1 :Normal Probability Standardized Residual}

Santoso (2001) menyatakan bahwa regresi yang bebas multikolinearitas ditandai dengan nilai $V I F$ dan nilai Tolerance berkisar angka 5. Artinya bila toleransi kecil menunjukkan nilai VIF yang besar. Untuk itu bila VIF > 5 maka dianggap terjadi multikolinearitas dengan variabel lainnya, sebaliknya jika diperoleh VIF $<5$ maka dianggap tidak terjadi multikolinearitas antara satu variabel independen dengan variabel independen lainnya dalam persamaan regresi.

\section{Tabel 4: Nilai Tolerance dan VIF}

\begin{tabular}{|l|c|c|l|}
\hline \multicolumn{1}{|c|}{ Variabel } & Tolerance & VIF & \multicolumn{1}{|c|}{ Keterangan } \\
\hline Keahlian & .778 & 1.285 & \multirow{2}{*}{ Tidak Terjadi } \\
Independensi & .510 & 1.959 & Multikolinearitas \\
Kecermatan Profesional & .601 & 1.663 & \\
\hline Etika & .566 & 1.768 & \\
\hline
\end{tabular}

Sumber: Pengolahan Data Hasil Penelitian, 2013

Pada Tabel 4. nilai Tolerance menunjukkan tidak ada variabel independen yang memiliki nilai Tolerance kurang dari 0.100 yang berarti tidak ada kolerasi antar variabel independen dan nilai (Variance Inflation Factor) VIF untuk variabel independen berkisar angka 5, VIF untuk setiap variabel independen < 5. Dengan demikian dapat disimpulkan bahwa variabel independen tidak mengalami gangguan multikolinearitas. 
Pemeriksaan terhadap gejala heterokedastisitas adalah dengan melihat pola diagram pencar (scatter plot). Jika diagram pencar yang ada membentuk pola-pola tertentu yang teratur maka regresi mengalami gangguan heterokedastisitas (Purwanto, 2004: 528).

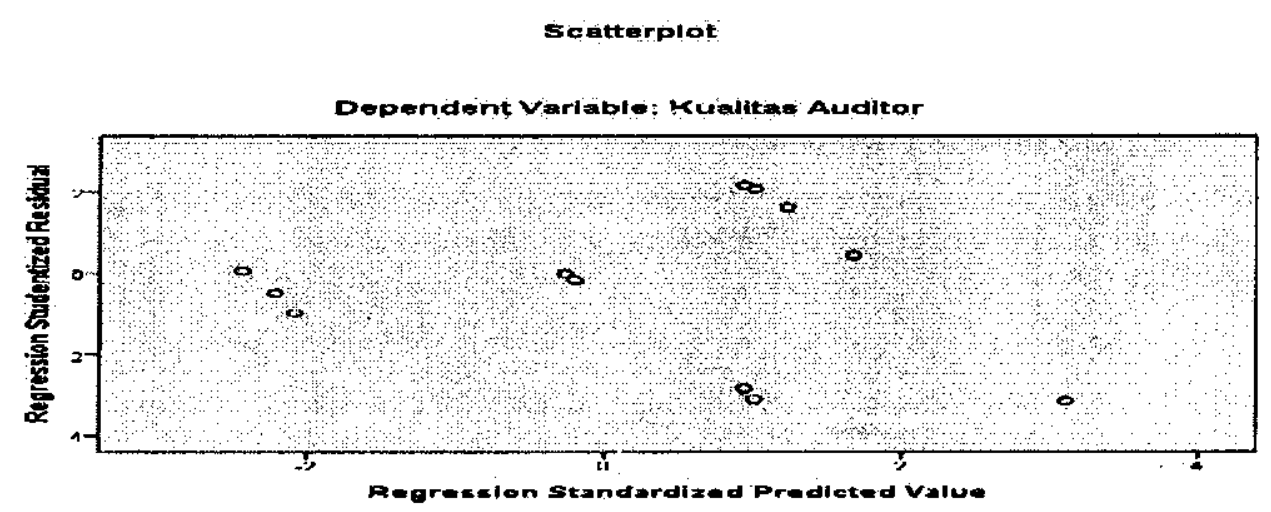

Gambar.2: Scatterplot

Autokorelasi pada penelitian ini dideteksi dengan nilai Durbin-Watson . Menurut Supranto (2001: 270) batas tidak terjadinya autokorelasi adalah angka Durbin-Watson berada antara -2 sampai dengan +2 .

Tabel 4: Statistik Durbin-Watson

\begin{tabular}{|c|c|c|}
\hline Deskriptif & Nilai Durbin-Watson & Keterangan \\
\hline $\begin{array}{c}\mathrm{N}=55 \\
\alpha=0,05\end{array}$ & 1,857 & Tidak terjadi autokorelasi \\
\hline
\end{tabular}

Sumber: Pengolahan Data Hasil Penelitian, 2013

Dari Tabel 4 dapat dilihat nilai statistik Durbin-Watson sebagai hasil output dari.SPSS Version 17.00 sebesar 0.600 . Hal ini membuktikan bahwa model analisis memenuhi syarat bebas autokorelasi yakni berkisar antara -2 sampai dengan +2 .

Uji interaksi ini digunakan untuk mengetahui sejauh mana interaksi variabel etika auditor dapat mempengaruhi keahlian, independensi, dan kecermatan profesional pada kualitas auditor. Model persamaan MRA yang digunakan:

$$
Y=a+b_{1} X_{1}+b_{2} X_{2}+b_{3} X_{3}+b_{4} x_{4}+b_{5} X_{1} X_{4}+b_{6} X_{2} X_{4}+b_{7} X_{3} X_{4}+e
$$

Hasil analisis regresi berganda dengan metode enter untuk model analisis dapat dilihat pada Tabel berikut: 
Tabel 5: Hasil Analisis Regresi

\begin{tabular}{|l|c|c|c|c|}
\hline \multicolumn{1}{|c|}{ Variabel } & B & t hitung & t Tabel & Signifikansi \\
\hline Konstanta & 9.384 & 7.205 & 2.000 & .000 \\
\hline Keahlian & .406 & 4.587 & 2.000 & .000 \\
\hline $\begin{array}{l}\text { Keahlian terhadap Kualitas } \\
\text { Auditor yang dimoderasi } \\
\text { Etika }\end{array}$ & .016 & 3.449 & 2.000 & .001 \\
\hline Independensi terhadap & .230 & 2.545 & 2.000 & .014 \\
\hline $\begin{array}{l}\text { Independensi Aualitas Auditor yang } \\
\text { dimoderasi Etika }\end{array}$ & 1.138 & 5.707 & 2.000 & .000 \\
\hline $\begin{array}{r}\text { Kecermatan Profesional } \\
\text { Kecermatan Profesional } \\
\text { terhadap Kualitas Auditor } \\
\text { yang dimoderasi Etika }\end{array}$ & 2.621 & 9.323 & 2.000 & .000 \\
\hline $\begin{array}{r}.668 \\
R^{2}=\end{array}$ & 3.225 & 2.000 & .002 \\
$F=$ & $\begin{array}{r}0,684 \\
0,672\end{array}$ & & & \\
\hline
\end{tabular}

Sumber: Pengolahan Data Hasil Penelitian, 2013

Berdasarkan hasil perhitungan regresi pada Tabel 4.19 diperoleh nilai dari $F_{\text {hitung }}$ dan $F_{\text {tabel }}$ sebagai berikut: $F_{\text {tabel }}=2.20$, artinya $F_{\text {hitung }}>F_{\text {tabel. }}$ Maka dapat disimpulkan bahwa model regresi yang digunakan dapat diterima dan bila dilihat dari nilai koefisien signifikansinya adalah lebih kecil dari 0.05 yakni sebesar o.ooo.

Dari Tabel tersebut hasil persamaan regresi dapat ditentukan sebagai berikut:

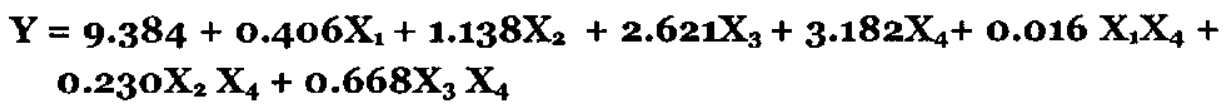

\section{Keahlian berpengaruh terhadap Kualitas Auditor}

Hasil pengolahan data diketahui $t$ hitung $(4,587)>t$ tabel $(2,000)$ dan nilai signifikan sebesar 0,000 dengan tingkat kesalahan (alpha) sebesar 0.05 . Oleh karena itu dapat disimpulkan bahwa keahlian berpengaruh signifikan terhadap kualitas Auditor.

\section{Etika akan mempengaruhi hubungan antara Keahlian dengan kualitas auditor}

Hasil pengolahan data diketahui $t$ hitung $(3,449)>t$ tabel $(2,000)$ dan nilai signifikan sebesar o,001 dengan tingkat kesalahan (alpha) sebesar 0.05. Oleh karena itu dapat disimpulkan bahwa keahlian yang dimoderasi oleh etika berpengaruh signifikan terhadap kualitas auditor. 


\section{Independensi berpengaruh terhadap Kualitas Auditor}

Hasil pengolahan data diketahui $t$ hitung $(5,707)>t$ tabel $(2,000)$ dan nilai signifikan sebesar 0,000 dengan tingkat kesalahan (alpha) sebesar 0.05 . Oleh karena itu dapat disimpulkan bahwa independensi berpengaruh signifikan terhadap kualitas auditor.

Etika akan mempengaruhi hubungan antara Independensi dengan Kualitas Auditor

Hasil pengolahan data diketahui t hitung $(2,545)>t$ tabel $(2,000)$ dan nilai signifikan sebesar 0,014 dengan tingkat kesalahan (alpha) sebesar 0.05. Oleh karena itu dapat disimpulkan bahwa independensi yang dimoderasi oleh etika berpengaruh signifikan terhadap kualitas auditor.

\section{Kecermatan Profesional berpengaruh terhadap Kualitas Auditor}

Hasil pengolahan data diketahui $t$ hitung $(9,323)>t$ tabel $(2,000)$ dan nilai signifikan sebesar 0,o00 dengan tingkat kesalahan (alpha) sebesar 0.05 . Oleh karena itu dapat disimpulkan bahwa kecermatan profesional berpengaruh signifikan terhadap kualitas auditor.

\section{Etika akan mempengaruhi hubungan Kecermatan Profesional dengan Kualitas Auditor}

Hasil pengolahan data diketahui $t$ hitung $(3,225)>t$ tabel $(2,000)$ dan nilai signifikan sebesar 0,002 dengan tingkat kesalahan (alpha) sebesar 0.05. Oleh karena itu dapat disimpulkan bahwa kecermatan profesional yang dimoderasi oleh etika berpengaruh signifikan terhadap kualitas auditor.

Berdasarkan Tabel 5. diperoleh nilai $R$ sebesar 0.827 dan $R$ Square $\left(R^{2}\right)$ sebesar 0.684. Besarnya Adjusted $R$ Square $\left(\mathrm{R}^{2}\right)$ sebesar 0.672 memberi pengertian bahwa $67.2 \%$ kualitas auditor dipengaruhi oleh keahlian, independensi, kecermatan profesional serta etika, sedangkan $32.8 \%$ dipengaruhi olëh väriabel Iainnya.

\section{PENUTUP}

\section{Kesimpulan}

1. Pengujian hipotesis pertama menunjukkan bahwa variabel keahlian memiliki pengaruh positif dan signifikan terhadap kualitas auditor.

2. Pengujian hipotesis kedua menunjukkan bahwa variabel keahlian yang dimoderasi oleh etika memiliki pengaruh yang positif dan signifikan terhadap kualitas auditor.

3. Pengujian hipotesis ketiga menunjukkan bahwa variabel independensi memiliki pengaruh yang positif dan signifikan terhadap kualitas auditor. 
4. Pengujian hipotesis keempat menunjukkan bahwa variabel independensi yang dimoderasi oleh etika memiliki pengaruh yang positif dan signifikan terhadap kualitas auditor.

5. Pengujian hipotesis kelima menunjukkan bahwa variabel kecermatan profesional memiliki pengaruh yang positif dan signifikan terhadap kualitas auditor.

6. Pengujian hipotesis keenam menunjukkan bahwa variabel kecermatan profesional yang dimoderasi oleh etika memiliki pengaruh yang positif dan signifikan terhadap kualitas auditor.

7. Hasil pengujian koefisien determinasi ( $\left.\mathrm{R}^{2}\right)$ sebesar 0.672 memberi pengertian bahwa $67,2 \%$ kualitas auditor dipengaruhi oleh keahlian, keahlian yang dimoderasi oleh etika, independensi, independensi yang dimoderasi oleh etika, kecermatan profesional, kecermatan profesional yang dimoderasi oleh etika. Jumlah koefisien determinasi sebesar 67,2 \% memberi gambaran bahwa masih ada sekitar $32,8 \%$ variabel lain yang mempengaruhi kualitas auditor.

\section{Saran}

1. Menambah variabel-variabel independen seperti program kerja pemeriksaan (PKP), kinerja dan kecukupan waktu serta variabel intervening yang memiliki kemungkinan untuk berpengaruh terhadap kualitas auditor.

2. Menambah jumlah sampel yang diteliti dan memperluas lokasi penelitian sehingga diharapkan tingkat generalisasi dari analisis akan lebih akurat.

3. Peneliti selanjutnya diharapkan dapat menggunakan data sekunder sebagai data penelitian seperti KKP, konsistensi atas laporan hasil audit dan data tugas pokok dan fungsi.

\section{DAFTAR PUSTAKA}

Alia, Ariesanti. 2001, Persepsi Auditor Terhadap Kualitas Audit. Tesis S2 Program Pasca Sarjana Universitas Gadjah Mada, Yogyakarta

Alim, M. Nizarul. 2007, Pengaruh Kompetensi dan Independensi terhadap Kualitas Auditor dengan Etika auditor sebagai variabel moderasi, SNA $\mathrm{X}$, Makassar.

Arens, Alvin A. James L. Loebbecke, 2008. Auditing Pendekatan Terpadu, Terjemahan oleh Amir Abadi Yusuf, Buku Dua, Edisi Indonesia, Salemba Empat. Jakarta.

Ashari, Ruslan. 2011. Pengaruh Keahlian, Independensi, dan Etika terhadap Kualitas Auditor pada Inspektorat Provinsi Maluku Utara. Skripsi. Fakultas Ekonomi Universitas Hasanuddin. Makassar.

Badan Pemeriksa Keuangan Republik Indonesia, 2007. Peraturan BPK-RI No. 1 tentang Standar Pemeriksaan Keuangan Negara (SPKN).

Bastian, Indra. 2007. Audit Sektor Publik, Edisi Kedua, Salemba Empat. Jakarta

Boyton C. William, Kell. G Walter dan Johnson N Raymond, 2002. Modern Auditing. Edisi Ketujuh. Jilid I. Erlangga. Jakarta. 
De Angelo, L.E. 1981. Auditor Independence, "Low Balling" and Disclosure Regulation. Journal of Accounting and Economics . pp. $113-127$.

Deis, D.R dan G.A. Groux. 1992. Determinants of Audit Quality in The Public Sector. The Accounting Review. Juli. pp. $426-479$.

Ghozali Imam, 2005. Aplikasi Analisis Multivariate dengan Program SPSS. Universitas Diponegoro. Semarang.

Huntoyungo, Siti Badriyah. 2009. Faktor - Faktor Yang Berpengaruh Terhadap Kualitas Audit. (Studi Pada Inspektorat Daerah Gorontalo). Tesis S2 Program Pasca Sarjana Universitas Diponegoro. Semarang.

IAPI. 2011. Standar Profesional Akuntan Publik. Salemba Empat. Jakarta.

Idriantoro, Nur dan Supomo, 2002. Metodologi Penelitian Bisnis untuk Akuntansi dan Manajement. Edisi Pertama. BPFE. Yogyakarta.

Kisnawati, Baiq. 2012. Pengaruh kompetensi, independensi, dan etika auditor terhadap kualitas audit (studi empiris pada auditor pemerintah di inspektorat kabupaten dan kota se-pulau lombok). Jurnal Bisnis dan Kewirausahaan. Vol. 8. pp. 4-9.

Lubis, Arifin. 2010. Faktor-faktor yang berpengaruh pada kualitas audit di Inspektorat Provinsi Gorontalo. Jurnal Keuangan dan Bisnis. Vol.2. pp.514.

Lubis, Haslinda. 2009. Pengaruh Keahlian, Independensi, Kecermatan Profesional dan Kepatuhan pada Kode Etik terhadap Kualitas Auditor pada Inspektorat Provinsi Sumatera Utara. Tesis S2 Sekolah Pascasarjana Universitas Sumatera Utara. Medan.

Mardiasmo, 2006. Perwujudan Transparansi dan Akuntabilitas Publik Melalui Akuntansi sektor Publik : Suatu Sarana Good Governance. Jurnal Akuntansi Pemerintah. Vol.2. pp.1-7.

Peraturan Menteri Pendayagunaan Aparatur Negara. (2008). Standar Audit Aparat Pengawasan Intern Pemerintah.

Samsi, Nur., Riduwan, Akhmad dan Suryono, Bambang. 2013. Pengaruh pengalaman kerja, independensi, dan kompetensi terhadap kualitas audit etika auditor sebagai variabel pemoderasi. Jurnal Ilmu dan Riset Akuntansi. Vol.1. pp. 4-17.

Watkins, Ann. L, William Hillison and Susan E. morecroft. 2004. Audit Quality: A Synthesis Of Theory And Empirical Evidence. Journal of Accoounting Literature Vol.23. pp.153-193 